\title{
Analysis of Gene Polymorphism CYP2C19 in the Lebanese Population Who Reside in Colombia
}

\author{
Mostapha Ahmad ${ }^{1}$, Elkin Navarro-Quiroz ${ }^{2}$, García Moreno Angélica Margarita ${ }^{3}$ Margarita Rosa Rios Anillo ${ }^{4}$, \\ Carlos Arturo Silvera Redondo ${ }^{4} \&$ Cecilia Fernandez Ponce ${ }^{5}$ \\ ${ }^{1}$ Docente investigador, Universidad Simón Bolívar, Facultad de Ciencias de la Salud, Barranquilla, Colombia \\ ${ }^{2}$ Docente investigador, Universidad Simón Bolívar, Facultad de Ciencias Básicas y Biomédicas, Barranquilla, \\ Colombia \\ ${ }^{3}$ Docente investigador, Universidad Simón Bolívar, Facultad de Ciencias de la Salud, Barranquilla, Colombia \\ ${ }^{4}$ Departamento de Medicina, Universidad del Norte, Km 5 via a Puerto Colombia, Barranquilla, Colombia \\ ${ }^{5}$ Universidad de Cádiz, Cádiz (España), Colombia \\ Correspondence: Elkin Navarro Quiroz, Universidad Simón Bolívar, Facultad de Ciencias Básicas y Biomédicas, \\ Barranquilla, Colombia. E-mail: enavarro26@unisimonbolivar.edu.co
}

Received: April 18, 2018 Accepted: May 20, 2018 Online Published: June 1, 2018

doi:10.5539/gjhs.v10n7p36 URL: https://doi.org/10.5539/gjhs.v10n7p36

\begin{abstract}
Background: The aim of this study is to determine the polymorphism of the CYP2C19 gene in the Lebanese population living in Colombia due to the lack of information and the importance of establishing its behavior which can predict a diminished or increased metabolism of medication related to it.

Methods and Results: 109 Lebanese volunteers residents of Colombia were included, genotypes for the CYP2C19 were detected by polymerase Chain Reaction-PCR finding that the most frequent allele was * $1(73.4 \%)$, followed by $* 2(26.6 \%)$ the allele $* 3$ was not found in the studied population. Only fast metabolites were found because of the $* 1 / * 1(73.4 \%)$ and $* 1 / * 2(26.6 \%)$ genotypes, any $* 1 / * 3, * 2 / * 2$ or $* 3 / * 3$ genotype were found.

Conclusions: The results obtained show a similar behavior with the alleles frequencies of the previous studies made in Colombia, Africa, Europe and other American population. Knowing the genotype of the population is important for the selection and adjustment of the doses of the best medication to give the optimal treatment in medical practice. The pharmacogenetics will reduce the adverse reactions during medical treatment for a better and more accurate clinical approach.
\end{abstract}

Keywords: CYP2C19, polymorphism, Lebanese, pharmacogenetics

\section{Introduction}

The variation in the human genome is one of the most important causes for the variability and unpredicted response to medications. The enzymatic expression and activity of the proteins related with it is determined by biological and environmental factors like the case of genetic polymorphism (Omura, 1999; Patricia \& Gordillo, 2008). Driven by advances in molecular biology, pharmacogenetics has evolved in recent years, and is currently one of the most active fields in applied biomedical research, focusing its efforts to the study of genetic aspects related to drug response in individuals or populations.

The cytochrome P450 is mainly responsible for the metabolism of drugs and other endogenous and exogenous substances(Malgor \& Valsecia, 2000; Okey, 1990). Multiple forms of the enzyme have been described, each of which is adapted to the metabolism of structurally related compound groups. Still, this versatility is unprecedented and no other enzyme substrates can accommodate disparate chemical nature. It would not be correct to say that any molecule (including next-generation chemical compounds) that comes into contact with the body could be metabolized to a greater or lesser extent, by the P-450. Another of the most significant features of the P-450 is its inducibility to own xenobiotics (Conney, 1986; Mansuy, 1994).

CYP2C19 gene (chromosome 10q24.1), is a fundamental part of the cytochrome P450 family, it is responsible for the metabolism of proton-pump inhibitor, antidepressants, S-mephenytoin, diazepam and other benzodiazepines, imipramine, propranolol and proguanil (Ingelman-Sundberg, Sim, Gomez, \& Rodriguez-Antona, 2007). 
CYP2C19 is involved in the metabolism of all proton pump inhibitors it can be anticipated that the largest part of the interindividual variability in the pharmacokinetics of this group of drugs is due to the CYP2C19 genotype of the treated patients. The polymorphism of $C Y P 2 C 19$ has first been described for the anticonvulsant S-mephenytoin and the proton pump inhibitors have been introduced as a tool for determining the CYP2C19 phenotype (Klotz, Schwab, \& Treiber, 2004). It is a polymorphic enzyme of which there are 15 known allelic variants, with a prevalence that presents a marked interracial variability, of which the most common are CYP $2 C 19 * 1$ (normal allele); $C Y P 2 C 19 * 2$ and $C Y P 2 C 19 * 3$, are two mutated alleles which present two fundamental sequence changes $\mathrm{G}$ $\mathrm{x} A$ in nucleotide 636 of exon 4 that gives rise to a premature stop codon. The change $\mathrm{G}$ x A in nucleotide 681 of exon 5 that causes an alteration in the process cuts splicing. Polymorphisms in the CYP genes have been extensively studied(Linden, Ziulkoski, Tonello, Wingert, \& Souto, 2009). Patients can be categorized into four types as follows: i) Poor metabolizer (PM); ii) intermediate metabolizer (IM); iii) extensive metabolizer (EM); and iv) ultrarapid metabolizer (UM)(Vangsted, Klausen, \& Vogel, 2012).

Around the 1880s the first Arab arrived to Colombia and this is when the first Arab names from Lebanon, Syria and Palestine began to appear(Viloria de La Hoz, 2003). The main causes of migration were primarily economical in addition to mistreatment by the Ottoman authorities, causing the start of emigration of this population to other countries. The migrants were mainly young and single men who have decided to leave the country after hearing the stories of the great wonders that existed on the continent of every opportunity: America.

The aim of this study is to determine the polymorphism of the CYP2C19 gene in the Lebanese population resident in Colombia due to the lack of information and the importance of an established behavior that can induce a diminished or increased metabolism of medication related to it. We consider this is an important work, for being one of the first at national and international level that studies the polymorphism of CYP2C19 gene in this population. It will also provide database for foreigners in Colombia and will be a start point for future work in genotype/phenotype where the polymorphisms of genes and clinical application are studied.

\section{Materials and Methods}

\subsection{Study Subjects}

The studied population was constituted by a chosen convenience of 109 Lebanese volunteers, composed of 38 women and 71 men between 18 and 75 years in three Colombian departments (Bolívar, Atlántico and Guajira) this group was formed by Lebanese with two Arab surnames, for parents and two Arab names for grandparents. The representative sample of the total population of Lebanese in Colombia was estimated depending on the number of Lebanese citizens residing in Colombia and was delivered by the National Administrative Department of Statistics DANE. This study was conducted according to the rules and objectives of the Helsinki Declaration adopted by the 18th World Medical Assembly, Helsinki, Finland, June 1964 and amended by the 29th World Medical Assembly, Tokyo, Japan, October 1975 35th World Medical Assembly, Venice, Italy, October 1983. (World Medical Association). Before conducting the tests each volunteer was informed verbally and written about all the objectives, protocols and study characteristics. They all gave their written consent to participate in it. The data collection protocol was filed, and each participant was given a key number so researchers could not relate the sample and information obtained with the identity of the participant. The research protocol was approved by the ethics committee of the Universidad Del Norte Foundation.

For all subjects, $5 \mathrm{ml}$ of blood was collected on EDTA after signing an informed consent and the sample was stored at $-70 \mathrm{C}$.

\section{CYP 2 C19*1, 2 and $* 3$ genotyping}

Genomic DNA was extracted using the Ultra Clean Blood DNA Isolation Kit and stored at -70C. DNA was amplified by Polymerase Chain Reaction (PCR) using the method of PCR with a pair of "confronted primers" PCR-CTPP, the Sequences of the oligonucleotides used as primers are shown in Table 1. 
Table 1. The Sequences of the oligonucleotides used as primers

\begin{tabular}{|c|c|}
\hline$* 2 \mathrm{~F} 1$ & $5^{\prime}$ agagcttggcatattgtatet $3^{\prime}$ \\
\hline$* 2 \mathrm{r} 1$ & $5^{\prime}$ taagtaatttgttatgggttcc $\underline{c} 3^{\prime}$ \\
\hline$* 2 \mathrm{f} 2$ & 5'ccactatcattgattatttccca 3 ' \\
\hline$* 2 \mathrm{R} 2$ & 5' TCGATTCTTGGTGTTCTTTTAC 3' \\
\hline$* 3 \mathrm{~F} 1$ & 5' AACCAGCTAGGCTGTAATTGT 3' \\
\hline *3R1 & 5' CTTGGCCTTACCTGGATC 3 ' \\
\hline$* 3 \mathrm{~F} 2$ & 5’ ATTGTAAGCACCCCCTGA 3' \\
\hline *3R2 & 5' CACTGATCAGGGAGCTAATG 3' \\
\hline
\end{tabular}

The major genotypes depend on a polymorphism in exon 4 (G636A) and exon 5 (G681A). The most serious type is the individual who has $681 \mathrm{G}$ allele $* 1$ and the 681 st would have the $* 2$ allele and / or would have $636 \mathrm{G}$ allele * 1 and the 636 th would have the allele * 3 . Because of this, the technique will result in a series of bands as follows:

A band of $131 \mathrm{bp}$ for $681 \mathrm{G}$ (Allele *1)

A band of 105 bp for $681 \mathrm{~A}$ (Allele *2)

A band of 191 bp for common allele *1 and *2 allele

A band of $377 \mathrm{bp}$ for $636 \mathrm{G}$ (Allele *1)

A band of $255 \mathrm{bp}$ for 636A (Allele *3)

A band of $597 \mathrm{bp}$ common for Allele 1 and Allele *3

The digested products visualized on a $3 \%$ agarose gel for the first position $C Y P 2 C 19 G 681 A(* 2)$ and on a $2 \%$ for the second position CYP2C19 G636A (*3), both stained with ethidium bromide. The bands were visualized using the Bio documenter (BIO RAD brand).

\subsection{Statistical Analysis}

Genotype frequencies were tested for deviations from the Hardy-Weinberg disequilibrium (HWE) through Chi-square analysis. Allelic and genotypic frequencies are verified by direct counting and/or statistical software STATA type (College Station, Texas) including the study of ORs and CIs regression models for adjustments of gender and age, and then a comparative analysis was conducted between the results obtained in this work and other works reported in the literature. The statistics program SPSS 20 values $\mathrm{P}<0.05$ were accepted as statistically significant.

\section{Results}

The main objective of this study was to determine the distribution of the main alleles of the CYP2C19 gene and to estimate the type of metabolizers present in the Lebanese population living in Colombia. The total samples studied was 109 participants: 38 women and 71 men.

Once the electrophoretic run was performed, the results were visualized, using Bio Rad document maker, the presence of the bands was analyzed, photos were taken and saved as shown in the following figures. 

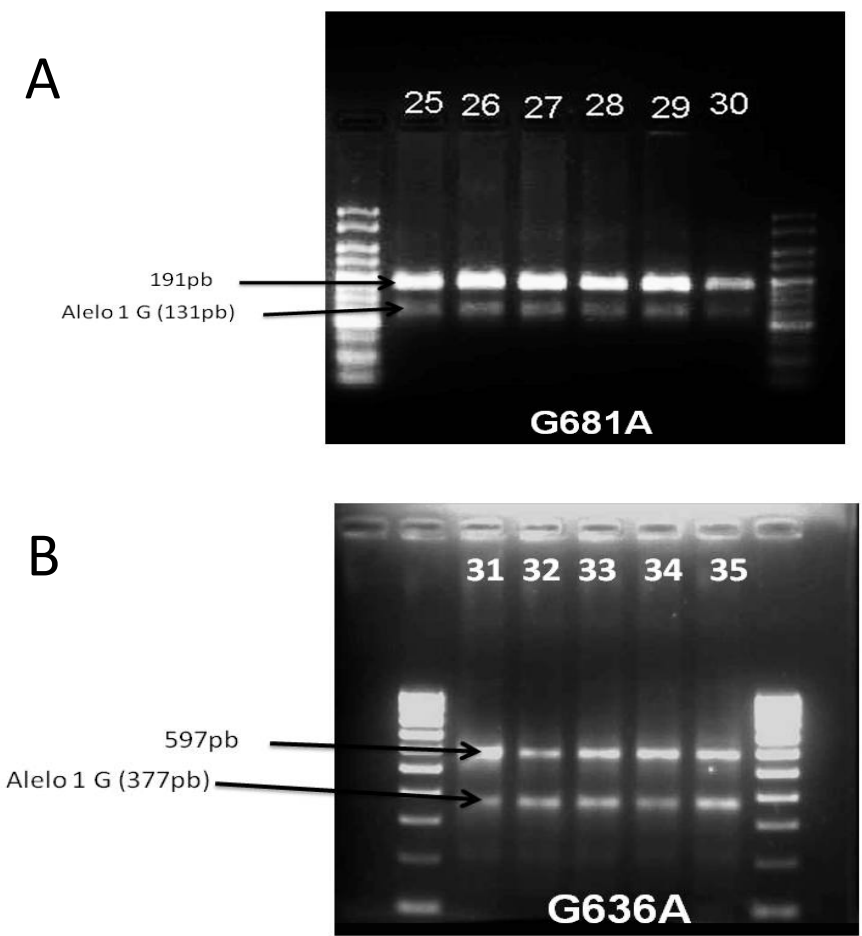

Figure 1. 2\% agarose gel electrophoresis for allele specific PCR for Allele (A) G681A, and (B) G636A

According to the study of CYP2C19 gene in the Lebanese population who reside in Colombia, the most frequent allele was * 1 with $73.4 \%$, followed by $* 2$ with $26.6 \%$ and $* 3$ with $0 \%$ (Table 2 ).

Table 2. Allelic frequencies of the CYP2C19 gene in the population residing in Colombia

\begin{tabular}{|c|c|c|c|c|c|}
\hline Alelos & & Frecuencia & Porcentaje & Frecuencia relativa & Interval de confianza al $95 \%$ \\
\hline & $* 1$ & 80 & 73,4 & 0,734 & $64,6-82,1$ \\
\hline & $* 2$ & 29 & 26,6 & 0.266 & $17,8-35,3$ \\
\hline & $* 3$ & 0 & 0 & 0,0 & 0,0 \\
\hline & Total & 109 & 100,0 & 1 & \\
\hline
\end{tabular}

The genotype $* 1 / * 1$ was found more frequently in the analyzed population in a $73.4 \%$. Then genotype $* 1 / * 2$ with $26.6 \%$ was found. Genotypes that were not found in this population were $* 1 / * 3, * 2 / * 2$ and $* 3 / * 3$. The association of phenotypes with polymorphism found in the studied subjects were all extensive metabolizers EM $(* 1 / * 1)$ and intermediate metabolizer $(* 1 / * 2)$, not getting any poor metabolizers PM (Table 3 ).

Table 3. Comparison phenotype/Genotype/Type of metabolizer

\begin{tabular}{llll}
\hline Genotype & Frequency & Percentage & Type of metabolizer \\
\hline$C Y P 2 C 19 * 1 / * 1$ & 80 & 73.4 & EM \\
$C Y P 2 C 19 * 1 / * 2$ & 29 & 26.6 & IM \\
Total & 109 & 100 & \\
\hline
\end{tabular}

PM: Poor Metabolizer- EM: Extensive Metabolizer- IM: Intermediate metabolizer.

\section{Discussion and Conclusions}

Polymorphism of CYP2C19 is the main cause for the large interindividual variability in the pharmacokinetics of 
various drug. In so called poor metabolizers and het extensive metabolizer's drug exposure (AUC) is about 5 and 3 -times higher, respectively than in extensive metabolizers. The pharmacodynamic response is clearly related to the AUC and clinical efficacy depends on the extent and duration of the effect of the drug

In the present study, we found the frequency of the CYP2C19*1 and CYP2C19*2 alleles of the CYP2C19 gene are present in the Lebanese population residing in Colombia with the different percentages: $73.4 \%$ and $26.6 \%$ respectively. The genotypes were: CYP2C19*1 // CYP2C19*1 with a percentage of $73.4 \%$, followed by CYP2C19*1 / CYP2C19*2: 26.6\% genotype.

Globally, the genotype $C Y P 2 C 19 * 1 / C Y P 2 C 19 * 1$ has been the most frequent, found in different populations: Colombian: 83.6\%(Isaza, Henao, Isaza Martínez, Sepúlveda Arias, \& Beltrán, 2007) , American-European (Goldstein et al., 1997; Ozawa et al., 2004), African-American (Goldstein et al., 1997; Ozawa et al., 2004), Australian (Lamba, Dhiman, \& Kohli, 2000) and Canada (Jurima-Romet et al., 1996). These behaviors are similar to the results obtained in this study. CYP2C19 gene polymorphism was observed among smaller ethnic groups and among older population groups.

Analyzing and comparing the allelic frequencies in the population studied with African populations, Southwest Asia and Caucasians, we see the similarities with respect to the allelic and genotypic frequencies where the allele $* 1$ has a frequency of $70-87 \%$, allele $* 2$ has $13-25 \%$ and the absence of allele $* 3$ in most of these populations. This explains the expansion of the Phoenician empire that currently located in the area occupied by Lebanon that began after the period of Cretan hegemony when the Phoenicians began to set up factories in various parts of the Mediterranean such as Cyprus, North Africa, Sicily territory and Iberian Peninsula (Ćernîk \& Viceník, 2010).

The polymorphism studied is an important element in the health field according to its influence as a metabolizer and/or protector for diseases related to it. Similarly, worldwide behavior was found in the polymorphism of CYP2C19 gene. In Table 4, analysis of European, African, Asian and Oceania populations are included, it is also possible to make an analysis of the great variability of this gene.

Table 4. CYP2C19 variants alleles distribution in diverse ethnic groups

\begin{tabular}{lllll}
\hline Ethnic groups & WT $(* \mathbf{1}) *$ & $\mathbf{m} \mathbf{1}(* \mathbf{2}) \dagger$ & $\mathbf{m} \mathbf{2}(* \mathbf{3})+$ & References \\
\hline No Asians & & & & \\
Palestine (Gaza strip) & 91.3 & 5.8 & 3 & 17 \\
Egypt & 88.8 & 11 & 0.2 & 21 \\
Israeli (jew) & 84 & 15 & 1 & 25 \\
\hline Caucasians & & & & \\
Iran & 86 & 14 & 0 & 23 \\
Saudi Arabia & 85 & 15 & 0 & 11 \\
Australian & 85 & 15 & 0 & 13 \\
Canadian (Inuit) & 89 & 11 & 0 & 14 \\
Swedish & 84.9 & 14.4 & 0.7 & 22 \\
Danish & 84 & 16 & 0 & 24 \\
American-European & 87 & 13 & 0 & 11,12 \\
\hline Asian & & & & \\
Sum of the Asian & 62 & 32 & 6 & 11,12 \\
Chinese-Taiwanese & 63 & 32 & 5 & 11 \\
Japanese & 67 & 23 & 10 & 11,12 \\
Philippine & 54 & 39 & 7 & 11,12 \\
Korean & 67 & 21 & 12 & 16 \\
Lebanese & 73.4 & 26.6 & 0 & Current Study \\
\hline
\end{tabular}




\begin{tabular}{lllll}
\hline $\begin{array}{l}\text { Southest of Asia } \\
\text { North India }\end{array}$ & 70 & 30 & 0 & 18 \\
\hline African & 75 & 25 & 0 & 11,12 \\
African-American & 81.5 & 18 & 0.5 & 16 \\
Bantu Tanzania & 85 & 13 & 2 & 19 \\
Ethiopia & 78 & 22 & 0 & 20 \\
Band & 87 & 13 & 0 & 20 \\
Zimbabwe & & & & \\
\hline
\end{tabular}

WT (*1)*: Wild type, Allele CYP2C19*1, $\mathrm{m} 1(* 2) \dagger:$ Mutation 1, allele CYP2C19*2, $\mathrm{m} 2(* 3)+:$ Mutation 2, allele CYP2C19*3.

Knowing the genotype of the population is of great importance for selecting and setting the appropriate drug dose to provide optimal treatment in clinical practice.

Pharmacogenetics will help reduce adverse reactions during treatment for a more accurate and favorable clinical outcome, the results obtained during this study clarify the polymorphism of this migrant population in South America being the first one in the area, enriching the Colombian and world wide data base for a better and more accurate clinical approach taking into account the importance of the personalized therapy for a better clinical outcome.

\section{Competing Interests Statement}

The authors declare that there are no competing or potential conflicts of interest.

\section{References}

Ćernîk, V., \& Viceník, J. (2010). On some methodological questions of historical knowledge [K niektorým metodologickým otázkam historického poznania]. Historicky Casopis, 58(2), 193-212. Retrieved from http://www.scopus.com/inward/record.url?eid=2-s2.0-77954951077\&partnerID=40\&md5=a174555539bbb $2 \mathrm{~d} 2 \mathrm{c} 8123 \mathrm{bce} 8283 \mathrm{f} 826$

Conney, A. H. (1986). Induction of microsomal cytochrome P-450 enzymes: The first Bernard B. Brodie lecture at $\begin{array}{lllll}\text { Pennsylvania State University. Life } & \text { Sciences, }\end{array}$ https://doi.org/10.1016/0024-3205(86)90103-7

Goldstein, J. A., Ishizaki, T., Chiba, K., De Morais, S. M. F., Bell, D., Krahn, P. M., \& Price Evans, D. A. (1997). Frequencies of the defective CYP2C19 alleles responsible for the mephenytoin poor metabolizer phenotype in various Oriental, Caucasian, Saudi Arabian and American black populations. Pharmacogenetics, 7(1), 59-64. https://doi.org/10.1097/00008571-199702000-00008

Ingelman-Sundberg, M., Sim, S. C., Gomez, A., \& Rodriguez-Antona, C. (2007). Influence of cytochrome P450 polymorphisms on drug therapies: Pharmacogenetic, pharmacoepigenetic and clinical aspects. Pharmacology and Therapeutics. https://doi.org/10.1016/j.pharmthera.2007.09.004

Isaza, C., Henao, J., Isaza Martínez, J. H., Sepúlveda Arias, J. C., \& Beltrán, L. (2007). Phenotype-genotype analysis of CYP2C19 in Colombian mestizo nidividuals. BMC Clinical Pharmacology, 7. https://doi.org/10.1186/1472-6904-7-6

Jurima-Romet, M., Goldstein, J. A., LeBelle, M., Aubin, R. A., Foster, B. C., Walop, W., \& Rode, A. (1996). CYP2C19 genotyping and associated mephenytoin hydroxylation polymorphism in a Canadian Inuit population. Pharmacogenetics, 6(4), 329-339. $\quad$ Retrieved from http://www.ncbi.nlm.nih.gov/pubmed/8873219

Klotz, U., Schwab, M., \& Treiber, G. (2004). CYP2C19 polymorphism and proton pump inhibitors. Basic and Clinical Pharmacology and Toxicology. https://doi.org/10.1111/j.1600-0773.2004.pto950102.x

Lamba, J. K., Dhiman, R. K., \& Kohli, K. K. (2000). CYP2C19 genetic mutations in North Indians. Clinical Pharmacology and Therapeutics, 68(3), 328-335. https://doi.org/10.1067/mcp.2000.109365

Linden, R., Ziulkoski, A. L., Tonello, P., Wingert, M., \& Souto, A. A. (2009). Relation between CYP2C19 phenotype and genotype in a group of Brazilian volunteers. Brazilian Journal of Pharmaceutical Sciences, 45(3), 461-467. https://doi.org/10.1590/S1984-82502009000300011 
Malgor, L., \& Valsecia, M. (2000). Farmacología general: Farmacocinética. In Farmacología Médica (pp. 13-32).

Mansuy, D. (1994). Cytochromes P-450 and model systems: great diversity of catalyzed reactions. Pure and Applied Chemistry, 66(4), 737-744. https://doi.org/10.1351/pac199466040737

Okey, A. B. (1990). Enzyme induction in the cytochrome P-450 system. Pharmacology and Therapeutics, 45(2), 241-298. https://doi.org/10.1016/0163-7258(90)90030-6

Omura, T. (1999). Forty years of cytochrome P450. Biochemical and Biophysical Research Communications. https://doi.org/10.1006/bbrc.1999.1887

Ozawa, S., Soyama, A., Saeki, M., Fukushima-Uesaka, H., Itoda, M., Koyano, S., ... Sawada, J.-I. (2004). Ethnic differences in genetic polymorphisms of CYP2D6, CYP2C19, CYP3As and MDR1/ABCB1. Drug Metabolism and Pharmacokinetics, 19(2), 83-95. Retrieved from http://www.ncbi.nlm.nih.gov/pubmed/15499174

Patricia, A. L. C. F., \& Gordillo, E. (2008). Los polimorfismos genéticos del Citocromo P450 y su relevancia en el metabolismo de xenobióticos Bioquímica del Breve historia del o rigen y evolución del CYP450. Analytical and Bioanalytical Chemistry.

Vangsted, A., Klausen, T. W., \& Vogel, U. (2012). Genetic variations in multiple myeloma II: Association with effect of treatment. European Journal of Haematology. https://doi.org/10.1111/j.1600-0609.2011.01696.x

Viloria de La Hoz, J. (2003). Lorica, una colonia árabe a orillas del río Sinú. Cuadernos de Historia Económica Y Empresarial, (10), 1-91. Retrieved from http://www.banrep.gov.co/sites/default/files/publicaciones/archivos/chee_10.pdf

\section{Copyrights}

Copyright for this article is retained by the author(s), with first publication rights granted to the journal.

This is an open-access article distributed under the terms and conditions of the Creative Commons Attribution license (http://creativecommons.org/licenses/by/4.0/). 